\title{
Nitzschia omanensis sp. nov., a new diatom species from the marine coast of Oman, characterized by valve morphology and molecular data
}

\author{
Ines BARKIA ${ }^{1 *}$, Chunlian $\mathrm{LI}^{2}$, Nazamid SAARI ${ }^{1} \&$ Andrzej WitKowsKI ${ }^{3}$
}

\author{
${ }^{\prime}$ Department of Food Science, Universiti Putra Malaysia, 43400 UPM, Serdang, Selangor, Malaysia; *Corresponding \\ author e-mail: ines.barkia@gmail.com, tel.+96895064058 \\ ${ }^{2}$ South China Normal University, Institute of Ecological Sciences, Guangzhou, China \\ ${ }^{3}$ PalaeoceanologyUnit, Faculty of Geosciences, University of Szczecin, Mickiewicza 18, PL-70-383, Szczecin, \\ Poland
}

\begin{abstract}
An unidentified diatom species belonging in the genus Nitzschia isolated from samples in the Omani coastal region of the Arabian Sea is the focus of the present study. This species has been successfully cultivated in the laboratory and DNA was harvested and sequenced. Light microscopy (LM) and scanning electron microscopy (SEM) examination of the strain revealed some distinct features, of which the ultrastructure of canal raphe and the absence of central nodule are the most remarkable ones. In terms of morphology, the strain being studied resembles taxa belonging in Nitzschia sect. Lanceolatae. However, our phylogenetic tree based on a three-gene dataset, comprising concatenated nuclear-encoded small-subunit ribosomal DNAs (SSU) and chloroplast encoded (rbcL and psbC) shows that our strain is sister to N. filiformis, which belongs in Nitzschia sect. Obtusae. This species that we have named Nitzschia omanensis, is thus far only known from the harsh coastal waters of Oman, which are characterized by very high daily temperatures and extremely low precipitation.
\end{abstract}

Key words: Arabian Sea, biodiversity, diatoms, new species, Nitzschia omanensis, Oman

\section{INTRODUCTION}

Species belonging in the diatom genus Nitzschia Hassall have long received much attention from scientists due to their importance in water quality assessment and biomonitoring (LANGE-Bertalot \& Simonsen 1978; Krammer \& LANGE-Bertalot 1997; Trobajo et al. 2004, 2013; Kelly et al. 2015; LANGE-Bertalot et al. 2017). In recent decades, the exploration of Nitzschia biodiversity has expanded to include biochemical research, especially since evidence of domoic acid production was recorded among some Nitzschia species such as N. navis-varingica Lundholm et Moestrup from the Vietnamese coast (Kotaki et al. 2000; LunDHOLM \& MoESTRUP 2000) and $N$. bizertensis Smida, Lundholm, Hlaili et Mabrouk from a Mediterranean lagoon along the coast of Tunisia (SMIDA et al. 2014). Although the use of SEM and molecular data for consistent identification are now commonplace (e.g. LundHolm \& MoEstruP 2000, 2002; KNATTRUP et al. 2007), species delimitation within Nitzschia remains very problematic, both among marine and freshwater taxa (MANn 1978; Krammer \& LANGE-Bertalot 1997;
WitKowsKi et al. 2004; TROBAJO et al. 2013, 2015; RIMET et al. 2014). This can be attributed to the increasing number of recently described taxa, the extreme range and poor documentation of intra-specific variability of both morphological and molecular characters, and the absence of detailed documentation on nomenclatural types (JAHN et al. 2004; TUDESQUE et al. 2008; TROBAJO \& Cox 2006; Trobajo et al. 2013).

Species of the genus Nitzschia are ubiquitous as they occur in many types of aquatic ecosystems, from freshwater to brackish or marine habitats (HASLE 1964; KRAMMER \& LANGE-Bertalot 1997; WitKowsKi et al. 2000; Spaulding et al. 2010; LANGE-Bertalot et al. 2017). Despite their ubiquitous distribution, studies on Nitzschia species have mainly covered fresh waters and to a lesser extent oceanic and marine habitat (e.g. Cleve \& Grunow 1880; Gandhi 1960; Mann 1978; KaCZMARSKa et al. 1986; Krammer \& LANGe-Bertalot 1997; Trobajo et al. 2013; Mann \& Trobajo 2014; WITKOWsKI et al. 2015). Research on the identification and distribution of Nitzschia species in the Arabian Sea is also very scarce. SIMONSEN (1974) studied planktonic 
diatoms during the Indian Ocean Expedition of RV "Meteor" 1964-1965 from different stations including 6 stations in the middle of the Gulf of Oman. SIMONSEN (op. cit.) identified 32 Nitzschia taxa with two species and one variety described as new to science. Later, WITKOWsKI et al. (2000) studied several species from Qurum Beach on the coast of Oman, and species of the genus Nitzschia were poorly represented. More recently, in a study dedicated to benthic diatoms located northward Kuwait marine waters, AL-YAMANI \& SABURovA (2011) recorded less than 20 Nitzschia species, but their identification was mostly limited to the genus level.

Oman, with a coastline on the Arabian Sea, is one of the most biologically productive regions of the world's oceans (LONGHURST 2007). Such high primary biological productivity has been evidenced by remotely-sensed satellite data on chlorophyll $a$ concentration (AL-AzRI et al. 2010; PIONTKOVSKI et al. 2011; SARMA et al. 2012). The coastal zone of Oman, with over $3,000 \mathrm{~km}$ in length, includes different topographic and geological features such as 'Sabkha' (salt-flats), 'khawrs' (lagoons), and stretches of sand, mountains, islands, and mangrove forests (Directorate GENERAL of NATURE Conservation 2010). In general, the main characteristics of the area are high salinity (ca. $36 \mathrm{ppt}$ ), arid climate, large daily and seasonal temperature fluctuations, and a vigorous system of monsoonal winds (JuPP et al. 1996). The Northeast (NE) monsoon that affects the region from November till April is weak and dry, whereas the Southwest (SW) monsoon that occurs from June to September is strong and moist. The strong upwelling induced by the Southwest monsoon is classified as one of the five most intense upwellings in the world (CURRIE 1992; ORMOND \& BANAIMOON 1994). It brings up nutrient-rich deep-water masses along the Somalia and Arabian coast in response to the Ekman transport and vorticity balance (SWALLOW 1984) and results in spectacular phytoplankton blooms (HAAKE et al. 1993a,b; TUDHOPE et al. 1996).

In view of the poor representation of Nitzschia species in marine environments in general, and the Arabian Sea in particular, we aim in the present investigation to isolate specimen of Nitzschia from 3 different sites along the coast of Oman, specifically from Al Wusta region and to provide an exact identification based on a detailed morphological description using scanning electron microscopy (SEM) and sequence information of three genes (SSU, psbC and rbcL). In this study, we describe Nitzschia omanensis Barkia I. et Ch. Li as a species new to science.

\section{Material ANd Methods}

Study sites description. The new species was isolated from three sites in Al Wusta region in Oman. This coastal area from Duqm to Ras Madrakah is a relatively large intertidal zone that is dominated by high cliffs with large salt marshes ('Sabkha') behind. It is exposed to strong monsoon winds in the summer. Soils along the beach are white and sandy. The inshore marine topography is characterized by a narrow continental shelf and a steep continental slope (MidDLE EAST SCIENTIFIC EQUIPMENT CORPORATION et al. 2010). The sampling sites are considered non-polluted due to the very low population density and to the local economic activity that is based on artisan fishery and animal husbandry. However, the recent construction of a large port in Duqm for minerals export (ASIAN INFRASTRUCTURE INVESTMENT BANK 2016) and the imminent construction of a crude oil storage terminal in Ras Markaz (BusinEss GatewAYS INTERNATIONAL 2017) could have severe impacts on the marine biodiversity in the future. The characteristics of the sampling sites are summarized in Table 1 .

Collection of samples and culture conditions. Seawater samples were collected from different locations between January and February 2015 using sterile 61 bottles. Salinity, pH and dissolved oxygen were measured in situ with a multiparameter handheld meter (Horiba, U52, Mfr \# 3200164501). Immediately after sampling, the seawater bottles were transported to the laboratory in Muscat and kept at room temperature during the transportation period of around $6 \mathrm{~h}$. Upon return to the laboratory, the samples were partially decanted, and unialgal cultures were prepared by isolation and purification techniques using serial dilution. Cultures were grown in $\mathrm{f} / 20$ medium (a ten-fold dilution of $\mathrm{f} / 2$ medium) (GuILlard 1975) at $24{ }^{\circ} \mathrm{C}$, with an irradiance of $\sim 200 \mu \mathrm{mol} . \mathrm{m}^{-2} . \mathrm{s}^{-1}$ and 18:6 h light: dark cycle. Afterwards, they were transferred to Szczecin Culture Collection (SZCZ) where they were maintained in $\mathrm{f} / 2$ culture medium.

Microscopic examination. The chloroplast morphology of live

Table 1. Water characteristics and description of the selected sampling sites.

\begin{tabular}{llllll}
\hline Name of site & GPS coordinates & $\begin{array}{l}\text { Salinity } \\
(\mathbf{p p t})\end{array}$ & $\mathbf{p H}$ & $\begin{array}{l}\text { DO } \\
\left(\mathbf{m g . \mathbf { l } ^ { - 1 }}\right)\end{array}$ & General Observations \\
\hline Duqm & $\begin{array}{l}19^{\circ} 30^{\prime} 32.98^{\prime \prime} \mathrm{N} \\
57^{\circ} 42^{\prime} 14.36^{\prime \prime} \mathrm{E}\end{array}$ & 34.9 & 6.83 & 4.56 & $\begin{array}{l}\text { Wide extended coastal beach, sandy } \\
\text { soil, flat tidal pool }\end{array}$ \\
Ras Markaz & $\begin{array}{l}19^{\circ} 11^{\prime} 04.62^{\prime \prime} \mathrm{N} \\
57^{\circ} 45^{\prime} 47.04^{\prime \prime} \mathrm{E}\end{array}$ & 33.8 & 7.36 & 6.19 & $\begin{array}{l}\text { Wide extended coastal beach, sandy } \\
\text { soil, calm beach }\end{array}$ \\
Ras Madrakah & $\begin{array}{l}18^{\circ} 58^{\prime} 06.2^{\prime \prime} \mathrm{N} \\
57^{\circ} 45^{\prime} 01.9 " \mathrm{E}\end{array}$ & 34.5 & 6.95 & 5.38 & $\begin{array}{l}\text { Exposed to strong wind in summer, } \\
\text { swell breaking on rocks }\end{array}$ \\
\hline
\end{tabular}


cells was observed using Nikon TS300 inverted microscope (Nikon Corporation, Tokyo, Japan) equipped with an $\times 100$ Plan Apochromatic oil immersion objective (n.a.=1.40) and differential interference contrast (DIC) optics. For LM of the valves, permanent slides were prepared from rinsed and cleaned material. Accordingly, a cell culture suspension was boiled with $30 \%$ hydrogen peroxide $\left(\mathrm{H}_{2} \mathrm{O}_{2}\right)$ for a few hours at $150^{\circ} \mathrm{C}$ and then rinsed 5 times with deionized water. The resulting cleaned diatom material was pipetted onto coverslips, dried and mounted on glass slides using Naphrax ${ }^{\circledR}$ mounting medium (Brunel Microscopes Ltd, Wiltshire, U.K.). LM observations of the cleaned material were made with a Zeiss Axio Imager M2 (Carl Zeiss, Jena, Germany) using a $\times 100$ Plan Apochromatic oil immersion objective (n.a. $=1.46$ ) equipped with DIC. For SEM examination, a few drops of cleaned material were put onto Whatman Nuclepore polycarbonate membrane filters (Fisher Scientific, Schwerte, Germany). Once dried, the membranes were mounted onto aluminum stubs and coated with gold-palladium or gold for ca. 3-5 minutes. SEM observations were performed at the University of Rzeszów, Faculty of Biology and Agriculture using a Hitachi SEM SU8010 Equipment.

DNA extraction and PCR amplification. Genomic DNA was extracted from clone SZCZCH1763 ( N. omanensis) during the exponential growth phase using the Genomic DNA NucleoSpin ${ }^{\circledR}$ Plant II Kit (Macherey-Nagel, Germany) according to the manufacturer's instructions. Nuclear-encoded small subunit ribosomal RNAs (SSU) and chloroplast-encoded (rbcL and psbC) were amplified by PCR using the primers described in LI et al. (2015). The $25 \mathrm{ul} \mathrm{PCR} \mathrm{reaction} \mathrm{contained} 2 \mu \mathrm{l}(20$ ng) purified DNA template; $2.5 \mu 110 \times$ Dream Taq buffer (including $20 \mathrm{mM} \mathrm{MgCl}$ ); $1 \mu \mathrm{l}$ Ultrapure dNTPs Set ( $5 \mathrm{mM}$ each); $0.5 \mu \mathrm{l}$ each primer $(10 \mu \mathrm{M}) ; 0.15 \mu \mathrm{l}$ Dream Taq DNA polymerase $\left(5 \mathrm{U} \mathrm{\mu l}^{-1}\right)$ and the remaining volumes were added with sterile distilled water. PCR conditions for SSU were as follows: $94{ }^{\circ} \mathrm{C}$ for $2 \mathrm{~min}, 35$ cycles of $\left(94^{\circ} \mathrm{C}\right.$ for $15 \mathrm{~s}, 55^{\circ} \mathrm{C}$ for $15 \mathrm{~s}, 72^{\circ} \mathrm{C}$ for $1 \mathrm{~min}$ and $35 \mathrm{~s}$ ), and final extension at 72 ${ }^{\circ} \mathrm{C}$ for $7 \mathrm{~min}$. PCR conditions for $\mathrm{psbC}$ and $\mathrm{rbcL}$ were the same as with SSU but with $53^{\circ} \mathrm{C}$ for annealing temperature and $1 \mathrm{~min}$ and $15 \mathrm{~s}$ for extension time. PCR products were purified using Exonuclease I \& Polar-BAP (EURx, Gdańsk, Poland). Sequencing reaction was conducted in Oligo.pl DNA Sequencing Laboratory IBB PAS, (Warsaw, Poland) using Big Dye terminator v. 31 sequencing chemistry and run on an $\mathrm{ABI}$ $3730 \mathrm{xl}$ sequencer.

Phylogenetic analyses. Maximum likelihood (ML) analysis was performed using a combined three-gene (SSU, rbcL and psbC) dataset including 263 diatom taxa (Table S1), which encompass centric diatoms, araphid diatoms and raphid diatoms. The DNA sequence consisted of a matrix of 4362 nucleotide (Supplementary data S1) composed of SSU (1-1757 bp), rbcL (1758-3230 bp) and psbC (3231-4362 bp). The secondary structural alignment of SSU sequences was performed by SSU-align (NAWROCKI 2009) using covariance models and the ambiguous sites with a PP less than the default of 0.9 were removed. Data were partitioned according to different genes, different codon positions (in case of chloroplast markers), and paired and unpaired sites (in case of SSU markers) with a GTR $+\mathrm{G}+\mathrm{I}$ model. Phylogenetic tree was reconstructed with 1,000 bootstrap replicates using rapid Bootstrap analysis in RAxML v8.1 (Stamatakis 2014). The best-scoring ML tree was chosen as the final tree, rooted with two strains of Bolidomonas pacifica with bootstrap values added to their corresponding nodes.

\section{RESULTS}

\section{Nitzschia omanensis Barkia I. et Ch. Li sp. nov. Description}

Light microscopy (Figs. 1-6): The frustules are rectangular in girdle view with 2 chloroplasts per cell, one towards each apex (Fig. 6). The valves are linear lanceolate with parallel, sometimes slightly constricted margins and acutely rounded apices. The length and width ranges are $31.0-46.0 \mu \mathrm{m}$ and $4.5-6.5 \mu \mathrm{m}$, respectively $(\mathrm{n}=15)$. The canal raphe is strongly eccentric. Transapical striae are parallel, and resolvable in LM with a stria density of 32-37 in $10 \mu \mathrm{m}$ (arrow in Fig. 3). They are composed of small areolae, difficult to resolve in LM. The fibulae are short and delicate, and in general somewhat unequally distributed (8-13 in $10 \mu \mathrm{m}$, arrowhead in Fig. 2). The two middle fibulae are not consistently more distant than other fibulae (arrowhead in Fig. 2).

Holotype: slide no. SZCZCH1763 in the Szczecin Diatom Culture Collection, University of Szczecin, Faculty of Geosciences, Poland. Strain ID: SZCZCH1763 deposited in the Andrzej Witkowski Diatom Collection.

Type habitat: coastal zone of Oman $\left(19^{\circ} 30^{\prime} 32.98^{\prime \prime} \mathrm{N}\right.$, $57^{\circ} 42^{\prime} 14.36 " \mathrm{E}$ ), collected by Ines Barkia, February 2015. Etymology: This new species is named for the country Oman from which it has been sampled.

Isotype: Slide no. BM 101963 deposited in the Natural History Museum, Cryptogamic Herbarium, London.

Valves are strongly eccentric $(n=20)$. Raphe canal is slightly elevated above the valve face. The raphe is filiform. External proximal raphe endings (central nodule) are absent with a raphe slit running through (Figs 7, 8, black arrow in Fig. 8). At the apices, the terminal raphe endings are strongly hooked in the same side of the valve and terminate on the mantle (arrowheads in Figs 12, 13). Valve face is flat; proximal valve mantle is shallow with two rows of areolae; distal valve mantle is formed by very narrow, hyaline stripe of silica. Transapical striae are parallel in the middle, becoming slightly radiate towards the apices, 32-37 in $10 \mu \mathrm{m}$ (Figs 7, 12, 13). Areolae are small and oblong to circular, $31-37.5$ in $10 \mu \mathrm{m}$. The areolae on the canal raphe are distinctly longer than those of the valve face and are transapically elongate (white arrow in Fig. 8). Each row of transapical striae corresponds to one elongate areola on canal raphe (arrows in Fig. 8).

Internally, the valve mantle is perpendicular to the valve face with two rows of areolae above the raphe slit as enclosed by the raphe canal. Fibulae are irregularly distributed along the valve length (arrowheads in Fig. 9). In SEM, the spaces between the fibulae are variable with the tendency to become larger towards the valve apices (Fig. 9). Fibulae are narrow and similar in shape, $8-13$ in $10 \mu \mathrm{m}$ (Fig. 11). Due to the flat position of the specimens in SEM, which mostly displays the valve face towards the observer, we were unable to find a specimen 
Table 2. Morphometric data of species that have the closest similarity to Nitzschia omanensis sp. nov.

\begin{tabular}{|c|c|c|c|c|c|c|}
\hline & $\begin{array}{l}\text { Length } \\
(\mu \mathrm{m})\end{array}$ & $\begin{array}{l}\text { Width } \\
(\mu \mathrm{m})\end{array}$ & $\begin{array}{l}\text { Striae } \\
\text { (in } 10 \mu \mathrm{m} \text { ) }\end{array}$ & $\begin{array}{l}\text { Fibulae } \\
\text { (in } 10 \mu \mathrm{m} \text { ) }\end{array}$ & $\begin{array}{l}\text { Central } \\
\text { nodule }\end{array}$ & Valve shape \\
\hline N. omanensis & $31-46$ & 4.56 .5 & $32-37$ & $8-13$ & No & $\begin{array}{l}\text { Linear lanceolate, } \\
\text { acutely rounded } \\
\text { apices }\end{array}$ \\
\hline N. filiformis & $27.0-150.0$ & $4-5$ & $29-34$ & $7-9$ & Yes & $\begin{array}{l}\text { linear to linear- } \\
\text { lanceolate, apices } \\
\text { acutely rounded }\end{array}$ \\
\hline N. sociabilis & $22.4-49.5$ & $3.5-4.5$ & Invisible & $8-11$ & & $\begin{array}{l}\text { lanceolate to rhom- } \\
\text { boid with acute } \\
\text { apices }\end{array}$ \\
\hline N. palea & 44.0 & 4.3 & Invisible & $11-13$ & Yes & $\begin{array}{l}\text { Lanceolate with } \\
\text { subcapitate apices }\end{array}$ \\
\hline$N$. intermedia & $50-101$ & $5.2-7.4$ & $23-25$ & $9-12$ & No & $\begin{array}{l}\text { linear with short, } \\
\text { wide, subcapitate } \\
\text { apices. }\end{array}$ \\
\hline
\end{tabular}

that clearly showed the internal raphe slit. Thus far, in the two slightly tilted specimens showing the raphe in the valve middle, the internal proximal raphe endings were absent (arrows in Figs 10,11). At apices, the raphe terminates in small helictoglossae. Internally, the transapical striae are composed of small transapically elongate areolae, positioned at the same level as the virgae (Fig. 11).

\section{Phylogenetic analysis}

In the present study, the phylogenetic tree was constructed with 263 diatoms taxa of which 72 were exclusively within the Bacillariaceae family. Eventually, the genera used for the study involved Nitzschia, Pseudonitzschia, Fragilariopsis, Denticula, Psammodictyon, Cylindrotheca, Tryblionella, Hantzschia and Bacillaria. Our phylogenetic analysis showed that the new taxon was positioned in a sister clade to $N$. filiformis with low support value (bv= 43 , not shown in the branched node, Figs. 14, S1). This low bootstrap value could be attributed to the missing molecular data of the newly-added Bacillariaceae clones, specifically SSU and psbC sequences. Obviously, the phylogenetic position of $N$. omanensis is still unresolved. However, it could be stated that $N$. omanensis belongs in the Bacillariaceae family within a larger, strongly-supported clade (bv $=97 \%$ ) that is composed of Nitzschia draveillensis, N. paleacea, N. acicularis, N. aequorea, $N$. sigmaformis, $N$. filiformis, $N$. palea, $N$. capitellata, $N$. lembiformis, $N$. pusilla, $N$. varelae and $N$. bergii. The phylogenetic tree (Fig. 14) demonstrated also that Nitzschia is paraphyletic genus, whereas Pseudonitzschia and Tryblionella are monophyletic.

\section{Ecology and Distribution}

Nitzschia omanensis was sampled from the upper subtidal zone (depth $<1 \mathrm{~m}$ ) of three sites in Al Wusta region in February 2015. The sampling involved water samples containing planktonic and tychoplantonic forms. This period of the year corresponds to the beginning of the NE monsoon, which triggers huge growth of phytoplankton. In this particular survey, an accurate abundance of phytoplankton was not measured. However, the phytoplankton populations from the collected water samples were dominated by medium sized chain-forming diatoms (up to $50 \mu \mathrm{m}$ ), including species of Chaetoceros, Bellerochea and Thalassiosira, as well as dinoflagellates such as Noctiluca scintillans. Satellite images from the sampling sites at that period could be found in the following link (https://earthobservatory.nasa.gov/IOTD/ view.php?id=85718).

$N$. omanensis was collected from water samples with a salinity of $34 \mathrm{ppt}$, a neutral $\mathrm{pH}$, and $\mathrm{DO}$ from 4.56 to 6.19 (Table 1). In view of the limited number of samples, it was difficult to define precisely the ecological amplitude and preferences of the species. Yet, the cultivation of $N$. omanensis in open ponds under ambient conditions (BARKIA et al. 2018) revealed that our new taxon had a high tolerance to desiccation as well as a strong resistance to bleaching agents. In fact, when the ponds were emptied for cleaning purposes, $N$. omanensis survived in the joints or cracks of the 'Plexiglas' ponds and re-appeared in co-culture with other uni-algal cultures. Such resistance to harsh and dry conditions might be attributed to its natural habitat which is classified as an extremely stressful marine environment (SHEPPARD et al. 1992). 

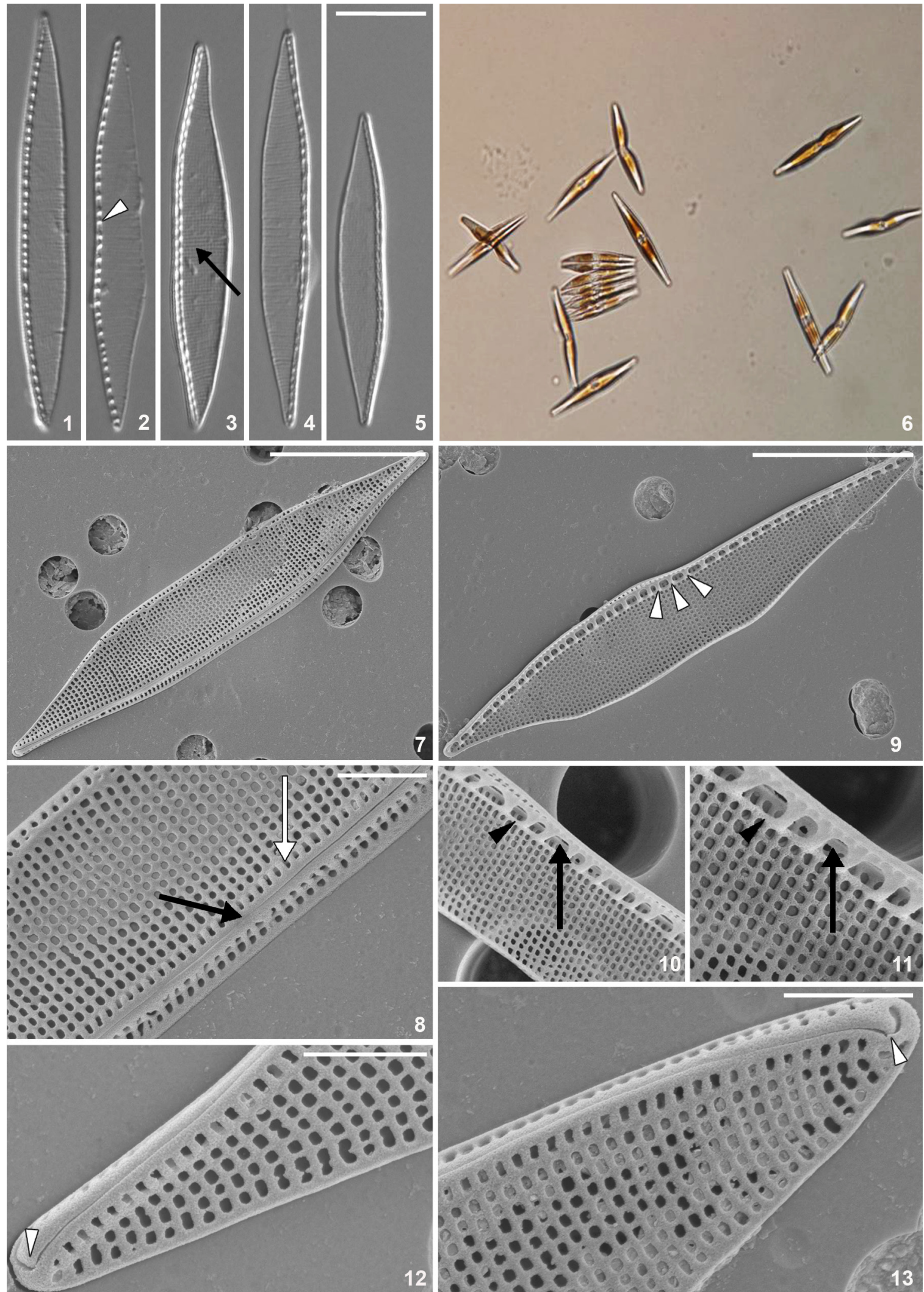

Figs 1-13. LM and SEM micrographs of Nitzschia omanensis Barkia I. et Chunlian Li sp. nov.: (1-5) LM micrographs of cleaned valves of Nitzschia omanensis strain SZCZCH1763. Specimen illustrated in Fig. 1 is holotype; note the presence of irregularly distributed fibulae (arrowhead, Fig. 2) and fine striae (arrow, Fig. 3); (6) LM micrographs of living specimens; (7-13) SEM micrographs of Nitzschia omanensis, (7) SEM external view of the whole specimen, (8) Close up of specimen illustrated in Fig. 7, note the continuous raphe external slit (black arrow) and canal raphe areola which are transapically elongate (white arrow); (9) SEM illustration of the valve interior; note the presence of irregularly distributed fibulae (arrowheads); $(10,11)$ Close up of the valve internal view; note the continuous raphe slit (black arrows in both images) and rib between canal raphe and valve face (black arrowheads in both images); $(12,13)$ Close up of the external view of the valve apical part; note the presence of strongly hooked apical raphe endings (arrowheads). Scale bar $10 \mu \mathrm{m}(1-7,9) ; 2 \mu \mathrm{m}(8,10-13)$. 


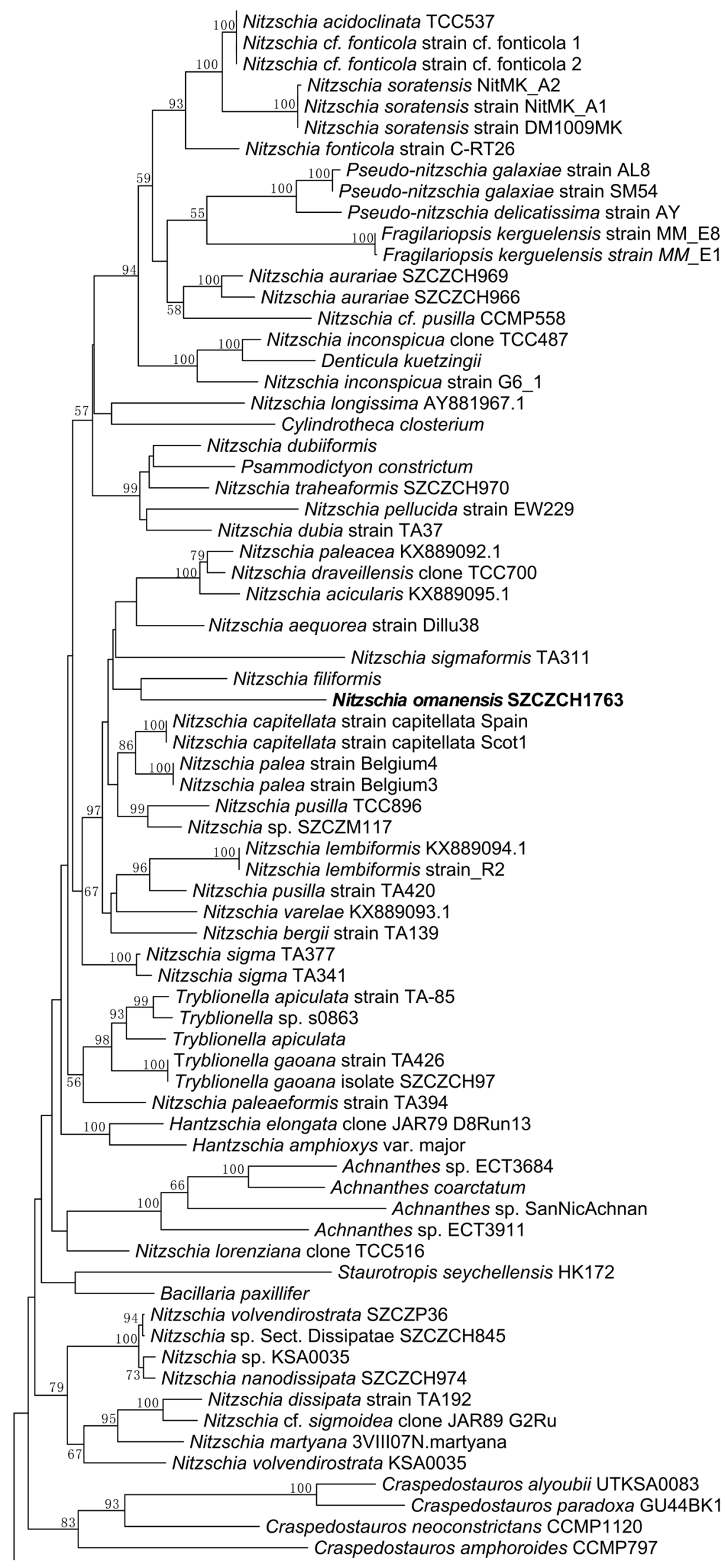

Fig. 14. Maximum likelihood phylogeny (with bootstrap values at nodes) inferred from three gene dataset, and only the topology with Bacillariaceae + Achnanthes + Craspedostauros was shown. The whole phylogenetic tree was illustrated in supplementary data Fig. S1. Nitzschia omanensis is bolded for clarity. Support values lower than $50 \%$ were not included in the tree. 


\section{Discussion}

Until today, the number of established Nitzschia species is estimated between 900 (MANN 1986) and 1314 (Kociolek 2017). However, due to the high degree of intraspecific morphological variability, the older descriptions of Nitzschia species have sometimes led to unreliable morphological diagnoses (RoviRA et al. 2015) and underestimated the ecology of some species (KeLly et al. 2015).

Difficulties in the identification of taxa belonging in Nitzschia arise broadly from the lack of unambiguous characters to group them. The routine identification of Nitzschia as bioindicators in ecological assessment is based upon the measurements of size (length, width), fibula, stria and areola linear density. But, in general the identification of Nitzschia species relies basically on morphological features such as the presence/absence of the break in the raphe slit, the central nodule, and the distance between the two middle fibulae (LANGE-BERTALOT \& Simonsen 1978; Trobajo et al. 2004). However, this approach can sometimes lead to unsatisfactory results (MANN 1982). In fact, some characters (e.g. size, stria and fibula density) may change drastically due to daily or seasonal variation in environmental conditions or within the cell cycle (Trobajo et al. 2012). For instance, it was demonstrated that length, width, stria and fibula density in N. frustulum (KÜTZING) GRUNOW were significantly affected by some physico-chemical parameters such as salinity, nutrients and water movement (TROBAJO et al. 2004).

Since morphological data on their own are insufficient to provide a rigorous taxonomic resolution, the use of a combined morphological and molecular examination is proposed to offer useful tools in troublesome cases like those of small Nitzschiae Lanceolate or the species complex of $N$. palea or $N$. capitellata. The distinction between two taxa, one possessing a central nodule $(N$. capitellata) and the other lacking a central nodule $(N$. palea) has a high phylogenetic and evolutionary significance (Trobajo et al. 2009).

However, in the present study, the likely position of Nitzschia omanensis within the section of Nitzschiae Lanceolatae and its phylogenetic relationship to a representative of Nitzschiae Obtusae demonstrates a low significance of sections in the taxonomy of Nitzschia as a genus. While the representative of Nitzschia sect. Lanceolatae may possess or not central nodule, all known Nitzschia sect. Obtusae possess a central nodule (LANGe-Bertalot \& Simonsen 1978; ManN 1982; KrAMMER \& LANGE-BERTALOT 1997).

The study of the morphological characteristics showed that Nitzschia omanensis is similar to the species of Nitzschia section Lanceolatae, such as $N$. capitellata Hustedt, and N. palea (Kützing) W. Smith (KRAMMER \& LANGE-BERTALOT 1997), particularly in terms of the strongly eccentric position of the raphe, the narrow mantle and the linear lanceolate valve shape
(Trobajo \& Cox 2006). However, Nitzschia omanensis is distinct from $N$. capitellata mainly by the absence of central raphe endings - the central nodule. Moreover, Nitzschia omanensis is easily distinguishable from $N$. palea in terms of the stria structure and canal raphe. In fact, Nitzschia palea has very fine striae composed of relatively robust virgae and significantly narrower areolae positioned between virgae, while the virgae in $N$. omanensis are somewhat narrower than areolae (Fig. 11). Besides, the raphe canal in $N$. omanensis is separated from the valve face by somewhat elevated narrow siliceous rib running between the fibulae (arrowhead in Fig. 12), whereas the contact between canal raphe and valve face in Nitzschia palea is flat (cf. Fig. 31 in Trobajo \& Cox 2006, and SEM Figures of valve interior in Trobajo et al. 2009). Nitzschia omanensis was also found to share similar morphological features with larger specimens of $N$. filiformis (sect. Obtusae), especially in terms of the linear to linear-lanceolate valve shape and stria density. While the absence of the central nodule in $N$. omanensis is argued sufficient to distinguish it from $N$. filiformis possessing a central nodule, the SEM microscopy depicts additional different features namely, the fibulae shape. In fact, fibulae are slightly irregular in N. omanensis but distinctly irregular in N. filiformis. The comparison of some morphometric data between species having similarity with Nitzschia omanensis sp. nov. is illustrated in Table 2.

Our phylogenetic tree showed that Nitzschia is a paraphyletic genus. This result corroborates well the studies of Trobajo et al. (2009), Rimet et al. (2011), Rovira et al. (2015) and WitKowski et al. (2015). Species belonging in Nitzschia cluster into several clades, each with moderate bootstrap support. The clade into which our strain is comprised contains species belonging in sections Lanceolatae (e.g. N. palea, N. paleacea, N. capitellata, N. pusilla, N. bergii, N. aequorea, N. acicularis), Obtusae (e.g. N. filiformis), and Sigmata (N. sigmaformis). Similar results based on 18S rDNA sequences were obtained by RIMET et al. (2011) who reported that the species from the above-mentioned sections were all found in one single clade. However, contrary to the works of RiMET et al. (2011) where some representatives of Nitzschia (e.g. N. palea, N. capitellata and N. aequorea) were well-supported towards the terminal branches of the tree (bv $=100 \%$ ), our new taxon was found in a clade with $N$. sigmaformis Hustedt and $N$. filiformis with low bootstrap support. Similarly, our results showed that $N$. omanensis formed a subclade with $N$. filiformis (sect. Obtusae) with significantly lower bootstrap value than those reported in BARKIA et al. (2018); bv $=99 \%$. This discrepancy could be explained by the lack of molecular and phylogenetic data describing either unknown or new species. The sister relationship between our species and $N$. filiformis underscores the true diversity of ecological and physiological tolerances among Nitzschia species. In fact, $N$. omanensis sp. nov. is a marine species by 
occurring in marine tropical waters, while $N$. filiformis is a brackish-water species that occurs in the tidal flats of the moderate climate zone, or in the inland waters with moderately high mineralization (KRAMMER \& LANGE-Bertalot 1997; LANGE-Bertalot et al. 2017). Information from the phylogenetic tree showed also that $N$. omanensis was genetically distant from the domoic acid-producing diatom Pseudo-nitzschia galaxiae (CERINO ET AL. 2005). Although it could be plausible to argue on the safety of our species, further biochemical analyses remain necessary to endorse the absence of neurotoxins (e.g. domoic acid).

The study of environmental data of the collected samples didn't show any striking features. In fact, $\mathrm{pH}$ was close to neutral and DO values were observed within the normoxia conditions $\left(4.5-6.2 \mathrm{mg} . \mathrm{l}^{-1}\right)$. The phytoplankton communities that support the marine ecosystem in the Arabian Sea at the sampling period (i.e. winter monsoon season) are largely understudied. A study conducted in Muscat region (Oman) showed that Nitzschia species represented only $13 \%$ of the total phytoplankton population in February, but were more abundant in July and October (AL-Hashmi et al. 2012). Similarly, another study done in the northwestern Arabian Gulf showed that Nitzschia genus with 14 taxa identified, had the lowest contribution $(0.79 \%)$ to the total phytoplankton community in winter season (PoliKarpov et al. 2016). Thus, it is suggested that an extensive year-round sampling from different geographic locations along the coast of Oman would be useful to determine the distribution and ecology of Nitzschia omanensis.

In conclusion, the new species Nitzschia omanensis sp. nov. sampled from marine tropical waters of the Arabian Sea was found to present similar morphological features with representatives of Nitzschia section Lanceolatae and was distinctive by the absence of central nodule. Nonetheless, the phylogenetic analysis suggests that our strain is sister to N. filiformis that belongs in Nitzschia sect. Obtusae.

\section{ACKNOWLedgMents}

Our sincere thanks are due to R. Jovine from Feed Algae (Oman) for his help during the sampling of microalgae. The authors acknowledge also the proofreading of the manuscript by Dr. Matt Ashworth from the University of Texas at Austin. The authors express their thanks to Łukasz Peszek from University of Rzeszów for his help in preparing SEM images. The contribution of $\mathrm{Ch}$. Li and $\mathrm{A}$. Witkowski has been performed within the frame of topical subsidy of the Polish Ministry of Science and Higher Education (No. 50311002303 88).

\section{REFERENCES}

Al-Azri A.R.; Piontkovski S.A.; Al-Hashmi K.; Goes J.G.; \& Helga Do R. (2010): Chlorophyll a as a measure of seasonal coupling between phytoplankton and the monsoon periods in the Gulf of Oman. - Aquatic Ecology 44: 449-461. doi: 10.1007/s10452-009-9303-2 Al-Hashmi, K.; Sarma, Y. V. B.; Claereboudt, M.; Al-Azri, A. R.; Piontkovski, S. A. \& AL-Habsi, H. (2012):
Phytoplankton Community Structure in the Bay of Bandar Khyran, Sea of Oman with Special Reference to Harmful Algae. - International Journal of Marine Science 2: 31-42.

Al-Yamani, F. Y. \& Saburova, M. A. (2011): Illustrated Guide on the Benthic Diatoms of Kuwait's Marine Environments. - 352 pp., Kuwait Institute for Scientific Research, Lucky Press, Kuwait.

ASIAN INFRASTRUCTURE INVESTMENT BANK (2016): Project document of the Asian Infrastructure Investment Bank. - pp. 1-43, Sultanate of Oman Duqm Port Commercial Terminal and Operational Zone Development Project. https://www. aiib.org/en/projects/approved/2016/_download/duqmport-commercial/document/20161213051938915.pdf

Barkia, I.; ZADJAli, F.; SAARI, N.; ZaKaria, M.H.; Li, L.CH.; WitKowsKI, A. \& AL-HAJ, L. (2018): Isolation and identification of indigenous marine diatoms (Bacillariophyta) for biomass production in open raceway ponds. - Aquaculture Research 49: 928-938.

Business GatewaYs INTERNATIONAL (2017): Oman Business News. Key agreement signed to develop RasMarkaz crude oil storage terminal. https://businessgateways.com/news/2017/07/06/ Agreement-for-RasMarkaz-crude-oil-storage-terminal

Cerino, F.; Orsini, L.; Sarnoa, D.; Dell'Aversanob, C.; TARTAGLIONE, L. \& Zingone, A. (2005): The alternation of different morphotypes in the seasonal cycle of the toxic diatom Pseudo-nitzschia galaxiae. - Harmful Algae 4: 33-48.

Cleve, P. T. \& Grunow, A. (1880): Beiträge zur Kenntniss der Arctischen Diatomeen. Kungl. - Svenska vetenskapsakademiens handlingar 17: 1-121.

CURRIE, R.I. (1992): Circulation and upwelling off the coast of south-east Arabia. - Oceanologica Acta 15: 43-60.

Directorate-General of Nature Conservation (2010): Fourth National Report of the Convention on biological Diversity. - 155 pp., Ministry of Environment and Climate Affairs Sultanate of Oman.

GANDHI, H. P. (1960): Some new diatoms from the Jog-Falls (Mysore state). - Journal Royal Microscopical Society 79: 81-87.

GuILLARD, R.R.L. (1975): Culture of phytoplankton for feeding marine invertebrates. - In: SMITH W. L. \& CHANLEY M. H. (eds): Culture of marine invertebrate Animals. - pp. 26-60, Plenum Press, New York, USA.

HaAke, B.; ItTeKKot, V.; RiXen, T.; RAmaswamy, V.; NAIR, R.R. \& CURRY W.B. (1993a): Seasonality and interannual variability of particle fluxes to the deep Arabian Sea. - Deep-Sea Research, 40:1323-1344.

HaAke, B.; Rixen, T. \& Ittekкot V. (1993b): Variability of monsoonal upwelling signals in the deep western Arabian Sea. - Mitteilungen aus dem GeologischPaläontologischen Institut der Universität Hamburg 76: 85-96.

HASLE, G.R. (1964): Nitzschia and Fragilariopsis species studied in the light and electron microscopes. I. Some marine species of the group Nitzschiella and Lanceolatae. - Skr. Norske Vidensk Akad. I. Mat. Nat. K1. N.S. 16: 1-48.

Jahn, R.; Kusber, W. H.; Medlin, L. K.; Crawford, R. M.; Lazarus, D. FriedL, T. et al. (2004): Taxonomic, molecular and ecological information on diatoms: the information system Alga Terra. - In Poulin, M. (ed.): Proceedings of the 17th International Diatom Symposium, - pp. 121-128, Biopress, Bristol, UK.

Jupp B.P.; Durako M.J; Kenworthy W.J; Thayer, G.W 
\& SCILlaK, L. (1996): Distribution, abundance, and species composition of seagrasses at several sites in Oman. - Aquatic Botany 53: 199-213.

KaczmarsKa, I. \& FryeXell, G.A. (1986): The diatom genus Nitzschia: Morphologic variation of some small bicapitate species in two Gulf Stream warm core rings. - In RICARD, M. (ed.): "Proceedings of the $8^{\text {th }}$ International Diatom Symposium”. - pp. 237-255, Koeltz, Koenigstein

Kelly M.G.; Trobajo R.; Rovira L. \& Mann D.G. (2015): Characterizing the niches of two very similar Nitzschia species and implications for ecological assessment. Diatom Research 30: 27-33.

Knattrup, A.Y. M.; Lundholm, N. \& EllegaArd, M. (2007): A detailed description of a Danish strain of Nitzschia sigmoidea, the type species of Nitzschia, providing a reference for future morphological and phylogenetic studies of the genus. - Diatom Research 22: 105-116.

KocioleK, J.P. (2017): Nitzschia A.H. Hassall, 1845. Accessed through: World Register of Marine Species at http://www. marinespecies.org/aphia.php? $\mathrm{p}=$ taxdetails\&id $=149045$ on 2017-10-22

Kotaki, Y.; Koike, K.; Yoshida, M.; Thuoc, C.V.; Huyen, N.T.M.; HoI, N.C.; FuKuYO, Y. \& Kodama, M. (2000): Domoic acid production of Nitzschia sp., isolated from a shrimp culture pond in Do Son, Vietnam. -Journal of Phycology 36: 1057-1060.

Krammer, K. \& LANGE-Bertalot, H. (1997): Bacillariophyceae 2. Teil: Bacillariaceae, Epithemiaceae, Surirellaceae. In: Ettl, H.; Gerloff, J.; Heynig H. \& Mollenhauer, D. (eds): Süßwasserflora von Mitteleuropa. - 611 pp., G. Fisher, Stuttgart.

LANGe-Bertalot, H. \& Simonsen, R. (1978): A taxonomic revision of the Nitzschia lanceolatae Grunow. 2 European and related extra European freshwater and brackish water taxa. -Bacillaria 1:11-111.

Lange-Bertalot, H.; Hofmann, G.; Werum, M. \& Cantonati, M. (2017): Freshwater benthic diatoms of Central Europe. - 942 pp., Koeltz Botanical Books, Schmitten-Oberreifenberg.

Li, C.L.; Ashworth, M.P.; WitKowski, A.; DĄBeK, P.; Medlin, L.K.; KooIstra W.H.C.F. et al. (2015): New Insights into Plagiogrammaceae (Bacillariophyta) Based on Multigene Phylogenies and Morphological Characteristics with the Description of a New Genus and Three New Species. - PlosOne 10: e0139300.

LONGHURST, A. (2007): Ecological Geography of the Sea. -299 pp., Academic Press, London.

Lundholm, N. \& Moestrup Ø. (2000): Morphology of the marine diatom Nitzschia navis-varingica, sp. nov. (Bacillariophyceae), another producer of the neurotoxin domoic acid. - Journal of Phycology 36: 1162-1174.

Lundholm, N. \& Moestrup Ø. (2002): The marine diatom Pseudonitzschia galaxiae sp. nov. (Bacillariophyceae): morphology and phylogenetic relationships. -Phycologia 41: 594-605.

ManN, D.G. (1978): Studies in the family Nitzschiaceae (Bacillariophyta) [PhD Thesis]. - University of Bristol, Bristol.

ManN, D.G. (1982): The use of the central raphe endings as a taxonomic character. - Plant Systematics and Evolution141: 143-152.

ManN, D.G. (1986): Nitzschia subgenus Nitzschia (Notes for a monograph of the Bacillariaceae 2). - In: RICARD, M. (ed.): Proceedings of the 8th International Diatom
Symposium. -pp. 215-226, Koeltz, Koenigstein.

Mann, D.G. \& Trobajo, R. (2014): Symmetry and sex in Bacillariaceae (Bacillariophyta), with descriptions of three new Nitzschia species. - European Journal of Phycology 49: 276-297.

Middle East Scientific Equipment Corporation LlC (MESEC), IDDE, \& CREOCEAN (2010): Atlas of Suitable Sites for Aquaculture Projects in the Sultanate of Oman. - pp. 1-233, Ministry of Fisheries Wealth, Sultanate of Oman.

NAWROCKI, E.P. (2009): Structural RNA homology search and alignment using covariance models [PhD Thesis]. - School of Medicine, Washington University in Saint Louis.

Ormond, R.F.G. \& BANAIMOON, S.A. (1994): Ecology of intertidal macroalgal assemblages on the Hadramout coast of southern Yemen, an area of seasonal upwelling. - Marine Ecology Progress Series 10:105-120.

PiontKovski, S.; Al-AzRI, A.; AL-Hashmi, K. (2011): Seasonal and interannual variability of chlorophyll-a in the Gulf of Oman compared to the open Arabian Sea regions. - International Journal of Remote Sensing 32: 7703-7715.

Polikarpov, I.; Saburova, M.; Al-Yamani, F. (2016): Diversity and distribution of winter phytoplankton in the Arabian Gulf and the Sea of Oman. - Continental Shelf Research 119: 85-99.

Rimet, F.; Kermarrec, L.; Bouchez A.; Hoffmann, L.; Ector, L. \& Meduin, L. K. (2011): Molecular phylogeny of the family Bacillariaceae based on $18 \mathrm{~S}$ rDNA sequences: focus on freshwater Nitzschia of the section Lanceolatae. - Diatom Research 26: 273-291.

Rimet, F.; Trobajo, R.; Mann, D.G.; Kermarrec, L.; Franc, A.; Domaizon, I.; Bouchez, A. (2014): When is Sampling Complete? The Effects of Geographical Range and Marker Choice on Perceived Diversity in Nitzschia palea (Bacillariophyta). - Protist 165: 245-259.

Rovira, L.; Trobajo. R.; SAto, S.; Ibanez, C. \& Mann, D G. (2015): Genetic and Physiological Diversity in the Diatom Nitzschia inconspicua. - Journal of Eukaryotic Microbiology 62: 815-832.

SARMA, Y.V.B.; AL-AzRI, A. \& SMITH, S. (2012): Inter-annual Variability of Chlorophyll-a in the Arabian Sea and its Gulfs. - International Journal of Marine Science 2:1-11.

Sheppard, C.R.C.; Price, A.R.G. \& Roberts, C.M. (1992): Marine Ecology of the Arabian Region: Patterns and Processes in Extreme Tropical Environments. - 359 pp., Academic Press, London.

Simonsen, R. (1974): The Diatom Plankton of the Indian Ocean Expedition of RV "Meteor" 1964 - 1965. - In: KREY, J.; BÜCKMANN, A.; KINNE, O. \& SCHÄFER, W. (eds): Meteor Forschungsergebnisse, Reihe D - No. 19, Biologie. Gebrüder Borntraeger. - 109 pp., Stuttgart, Berlin.

Smida, B.D.; Lundholm, N.; KoOISTRa W.H.C.F.; SAhraoui I.; RugGiero, M.V.; KotaKi, Y. et al. (2014): Morphology and molecular phylogeny of Nitzschia bizertensis sp. nov. -A new domoic acid-producer. - Harmful Algae 32: 49-63.

SPAulding, S.A.; LubinSKi, D.J. \& Potapova, M. (2010): Diatoms of the United States. http://westerndiatoms. colorado.edu. Accessed on 6/12/2016

Stamatakis, A. (2014): RAxML Version 8: A tool for Phylogenetic Analysis and Post-Analysis of Large Phylogenies. Bioinformatic 30: 1312-1313.

Trobajo, R.; Clavero, E.; Chepurnov, V.A.; Sabbe, K.; Mann, D. G.; IshiHARA, S. \& Cox, E.J. (2009): Morphological, 
genetic and mating diversity within the widespread bioindicator Nitzschia palea (Bacillariophyceae). Phycologia 48: 443-459.

Trobajo, R., \& Cox, E.J. (2006): Examination of the type material of Nitzschia frustulum, N. palea and N. palea var. debilis. - In: A. Witkowski (ed.): Proceedings of the eighteenth international diatom symposium. - pp. 431-445, Biopress Limited, Bristol.

Trobajo, R.; Cox, E.J. \& Quintana, X.D. (2004): The effects of some environmental variables on the morphology of Nitzschia frustulum (Bacillariophyta), in relation to its use as bioindicator. - Nova Hedwigia 79: 433-445.

Trobajo, R.; Rovira, L.; Ector, L.; Wetzel, C. E.; Kelly, M. \& ManN, D. G. (2013): Morphology and identity of some ecologically important small Nitzschia species. - Diatom Research 28: 37-59.

Tudesque, L.; Rimet, F.; \& Ector, L. (2008): A new taxon of the section Nitzschiae lanceolatae Grunow: Nitzschia costei sp. nov. compared to $N$. fonticola Grunow, $N$. macedonica Hustedt, $N$. tropica Hustedt and related species. - Diatom Research 23: 483-501.

Tudhope, A.W.; Shimmield, G.B.; Chilcott, C. P.; \& Head S. (1996): Monsoon climate and Arabian Sea coastal upwelling recorded in massive corals from Southern Oman. - Palaios 11: 347-361.

Witkowski, A.; Lange-Bertalot, H. \& Metzeltin, D. (2000): Diatom flora of marine coasts I. - Iconographia Diatomologica 7: 1-925.
Witkowski, A.; Lange-Bertalot, H.; Kociolek, J. P.; Ruppel, M .; WAWrZyNiAK-WydrowsKa, B., BAK, M. \& BrZEZINSKA, A. (2004). Four new species of Nitzschia sect. Tryblionella (Bacillariophyceae) resembling $N$. parvula. - Phycologia 43: 579-595.

Witkowski, A.; LANGe-Bertalot, H.; Kociolek, J.P.; BąK, M.; Kulikovskiy, M.S. \& Kuznetsova, I. (2015): Diatom flora of San Francisco Bay and vicinity III. New species in the genus Nitzschia Hassall. - Nova Hedwigia, Beiheft 144: 211-228.

\section{Supplementary material}

the following supplementary material is available for this article:

Table S1. Strains used for phylogenetic tree construction and their accession numbers.

This material is available as part of the online article (http:// fottea.czechphycology.cz/contents)

(C) Czech Phycological Society (2019)

Received November 30, 2018

Accepted June 17, 2019 